prof.dr hab. inz. Franciszek Tomaszewski

Politechnika Poznańska

mgr in.. Estera Wojciechowska

Instytut Pojazdów Szynowych ,TABOR”

\title{
Metodyka obliczania poziomu dźwięku generowanego przez tabor kolejowy
}

\begin{abstract}
Poprawa stanu środowiska i jakości terenów zurbanizowanych oraz zapewnienie zdrowego środowiska życia mieszkańcom państw europejskich to główne cele założone przez organy Unii Europejskiej. Ważnq role odgrywa w tym programie również walka z hałasem generowanym przez pojazdy szynowe. W artykule przedstawiono analize metod szacowania poziomu hałasu od pociagów opracowanych w krajach europejskich i innych. Główna uwaga zwrócona została na metodę holenderska, która jest rekomendowana przez UE.
\end{abstract}

\section{Wstęp}

Systematyczne rozszerzanie UE o nowe państwa, w tym Polskę wywołało szereg zmian prawnych $\mathrm{w}$ wielu dziedzinach nauki, również tych zajmujących się hałasem. Ogłaszane sukcesywnie przez Komisje UE nowe dyrektywy (np. 2001/16/WE [1], 2002/49/WE [2]) oraz normy (np. EN ISO 3095 [3]) mają na celu ujednolicenie przepisów dotyczących pomiarów poziomu hałasu, $\mathrm{w}$ tym również hałasu generowanego przez pojazdy szynowe. Dyrektywy te obliguja państwa członkowskie do dostosowania się do nich lub sporządzenia własnych krajowych przepisów (np. Ustawa „Prawo Ochrony Środowiska” [4], Rozporządzenia Ministra Środowiska itp.) nie odbiegających merytorycznie od unijnych.

W dziedzinie obliczeń poziomu hałasu generowanego przez pojazdy szynowe do środowiska zalecaną metodą jest nazywana powszechnie „Metoda Holenderska"[5]. Jednak wiele krajów opracowało i stosuje własne modele (metody) pozwalające szacować poziom hałasu generowanego przez pojazdy szynowe, uwzględniające zarówno warunki środowiskowe jak i aspekt techniczny taboru w danym kraju. Modele te są na różnym poziomie szczegółowości od prostych (jedno lub dwu parametrycznych) do złożonych posiadających dużą liczbę parametrów.

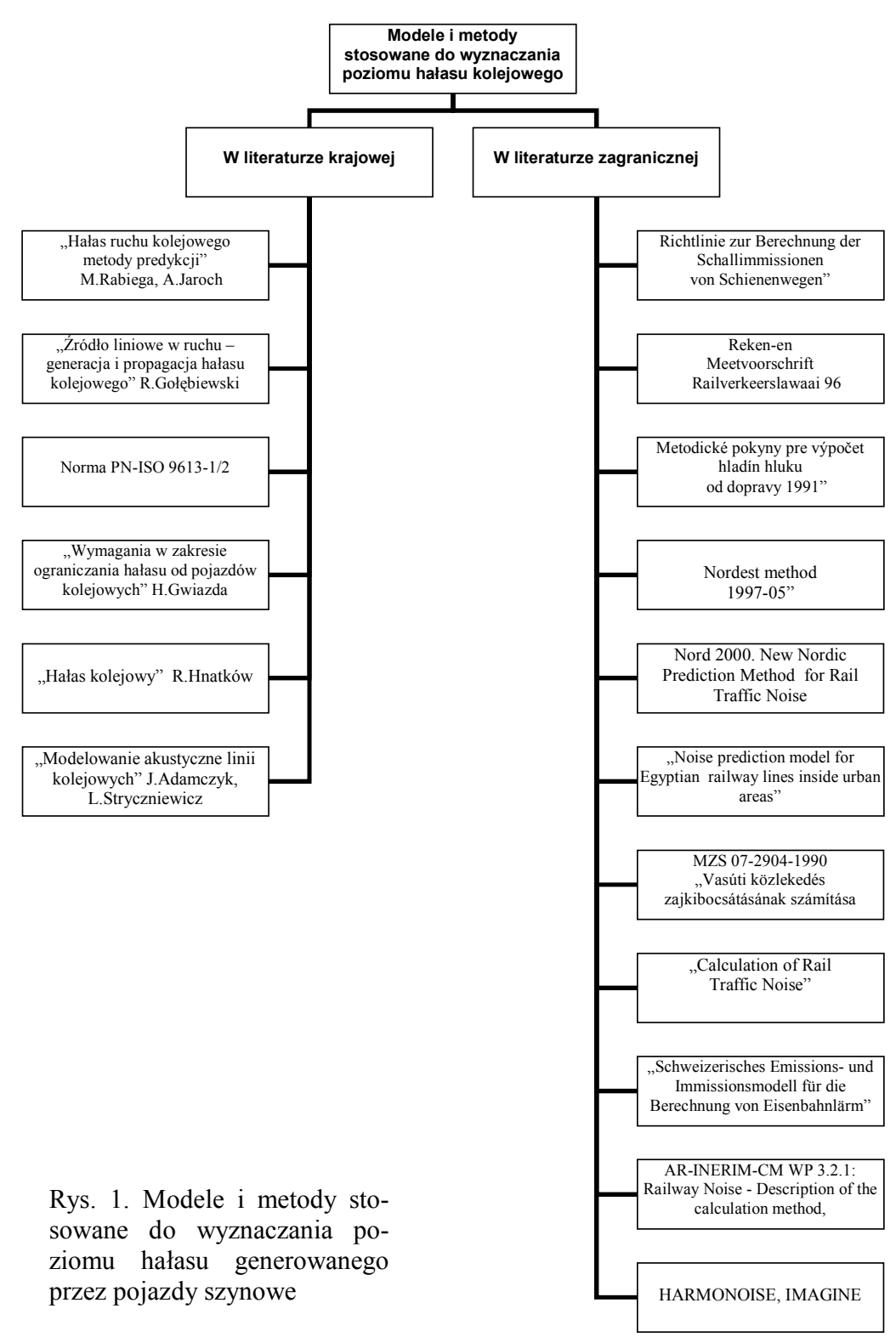

Rys. 1. Modele i metody stoziomu hałasu generowanego HARMONOISE, IMAGINE 
Wydaną w 08.2005r. normę EN ISO 3095 (PNEN ISO 3095) [3] stosuje się do badań poziomu hałasu na zewnątrz pojazdów szynowych a wartości dopuszczalne określone zostały w załączniku Dyrektywy UE 2006/66 [22]

Analiza literatury krajowej jak i zagranicznej pozwoliła na wyodrębnienie kilkunastu modeli i metod wykorzystywanych do wyznaczania (szacowania) hałasu od pojazdów szynowych, co zostało przedstawione na rysunku 1. Istotę tych metod przedstawiono w niniejszej pracy, w której zawarto również wybrane modele (metody) wykorzystywane w innych krajach, nie tylko europejskich, do oceny poziomu hałasu generowanego i propagowanego przez pojazdy szynowe do środowiska.

\section{Modele stosowane do wyznaczania poziomu hałasu kolejowego}

2.1. Metoda holenderska (,Reken-en Meetvoorschrift Railverkeerslawaai 96") wg ARINTERIM-CM [5],

Pierwsza wersja „Metody holenderskiej” powstała w 1996r, w kolejnych latach wprowadzano do niej poprawki wynikające ze zmieniającego się prawa. Metoda została zarekomendowana przez UE jako oficjalna metoda do wyznaczania poziomu hałasu generowanego przez pojazdy szynowe w krajach Unii Europejskiej.
Zredagowany przez Wölfel Meßsysteme Software GmbH \& Co projekt AR-INTERIM-CM, zawierający thumaczenie tzw. Metody Holenderskiej z języka holenderskiego na angielski, znacznie przybliżył sposób wykorzystywania tejże metody. W poszczególnych rozdziałach opracowania przedstawiono m.in. kategorie pojazdów szynowych, standardową metodę obliczeniową (SRM I) oraz obliczenia propagacji hałasu w poszczególnych pasmach oktawowych (SRM II) [6].

W metodzie wszystkie pojazdy, które używane są na określonych liniach kolejowych podzielone zostały na kategorie (rysunek 2) ze względu na rodzaj napędu oraz zastosowany system hamulcowy.

\section{Kategoria 1 - Pociagi pasażerskie wyposażone w hamulce klockowe}

- $\quad$ wyłącznie elektryczne pociagi pasażerskie z hamulcami klockowymi wyposażonymi we wstawki żeliwne $\mathrm{z}$ odpowiednio dobraną lokomotywą dla danego rodzaju składu pociągu, zarówno pociagi serii 1964 z Holandii jak i pociągi pasażerskie należące do Kolei Niemieckich (DB);

elektryczne pojazdy trakcyjne (w Holandii - np. pociagi pocztowe)

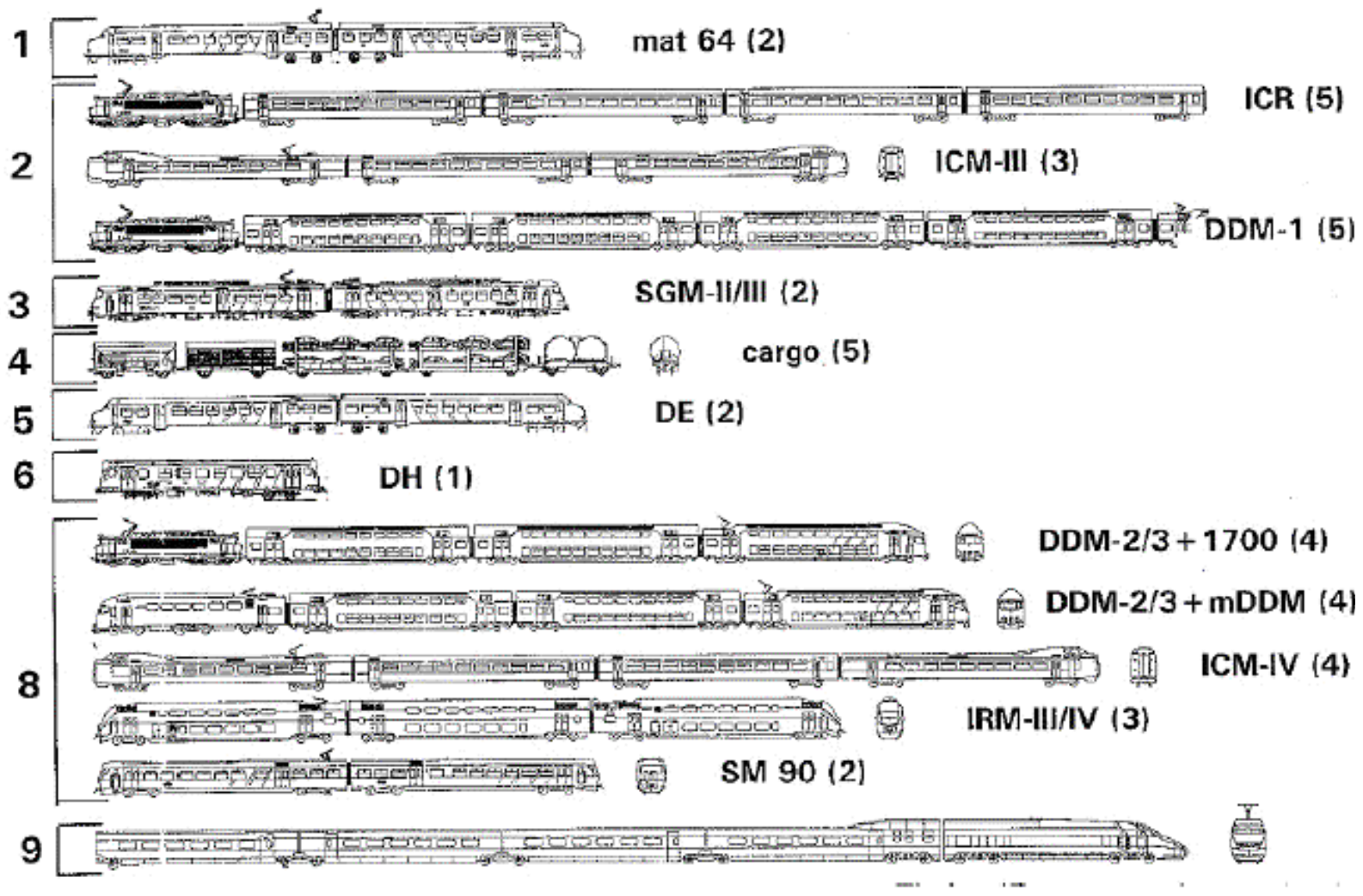

Rys. 2 Kategorie pojazdów szynowych wykorzystywanych w metodzie RMR 
Kategoria 2 - Pociqgi pasażerskie wyposażone w hamulce tarczowe oraz klockowe

elektryczne pociagi pasażerskie wyposażone głównie w hamulce tarczowe i dodatkowym hamulcem klockowym ze wstawkami żeliwnymi z odpowiednio dobraną lokomotywą dla danego rodzaju składu pociagu, np. IntercityMaterial IMC-III i DDM-1,

- pociagi pasażerskie należące do Kolei Francuskich (SNCF) i Trans Europe Express (TEE),

- $\quad$ lokomotywy elektryczne np. należące do Kolei Belgijskich (B) serii 1100, 1200, 1300, 1500, 1600 i 1700

Kategoria 3 - Pociagi pasażerskie wyposażone w hamulce tarczowe

wyłącznie pociągi pasażerskie $\mathrm{z}$ hamulcami tarczowymi np. pociagi regionalne (SGM, Sprinter).

Kategoria 4 - Pociagi towarowe wyposażone w hamulce klockowe

- $\quad$ wszystkie rodzaje pociągów towarowych z hamulcami klockowymi ze wstawkami żeliwnymi

Kategoria 5 - Pociagi spalinowe wyposażone w hamulce klockowe

- $\quad$ spalinowe pociagi pasażerskie o napędzie spalinowo - elektrycznym, wyposażone $\mathrm{w}$ hamulce klockowe ze wstawkami żeliwnymi $\mathrm{z}$ odpowiednio dobraną lokomotywą dla danego rodzaju składu pociagu, np. typy DE I, DE II, DE III;

- $\quad$ spalinowo - elektryczne lokomotywy, np.: lokomotywy serii 2200/2300 i 2400/2500.

Kategoria 6 - Pociagi spalinowe wyposażone w hamulce tarczowe

spalinowe pociagi pasażerskie $\mathrm{z}$ przekładnią hydrauliczną wyposażone w hamulce tarczowe

Kategoria 7 - Metro i szybka kolej miejska (np. tramwaje) wyposażone $w$ hamulce tarczowe

Metro i pociagi podmiejskiej szybkiej kolei

Kategoria 8 - Intercity oraz pociagi jeżdżq̨e z mniejszymi prędkościami wyposażone w hamulce tarczowe

wyłącznie elektryczne pociąi pasażerskie $\mathrm{z}$ hamulcami tarczowymi z odpowiednio dobraną lokomotywą dla danego rodzaju składu pociagu, np.: typy InterCities - ICM IV, IRM i SM90;

elektryczne pociągi pasażerskie głównie $\mathrm{z}$ hamulcami tarczowymi i dodatkowym hamulcem klockowym ze wstawkami spiekanymi lub żeliwnymi np. ABEX z odpowiednio dobraną lokomotywą dla danego rodzaju składu pociagu, np.: typy InterCities - ICM III i DDM-2/3.
Kategoria 9 - Pociqgi dużych prędkości z hamulcami klockowymi i tarczowymi

elektryczne pociagi pasażerskie głównie $\mathrm{z}$ hamulcami tarczowymi i dodatkowym hamulcem klockowym ze wstawkami żeliwnymi na wagonie silnikowym, np.: typy TGV-PBA lub HLSSouth.

Kategoria 10 - Tymczasowo zarezerwowana dla pociagów du̇̇ych prędkości typu ICE-3 (M) (HST East)

Pojazdy nie wymienione powyżej przydziela się do stosownej kategorii bazując na ich systemie napędnym i hamowania lub maksymalnej prędkości (tabela 1).

W metodzie sklasyfikowano rodzaje torowisk:

- $\quad$ tory kolejowe z szyn bezstykowych na podkładach betonowych (pojedynczych lub podwójnych), na podsypce thuczniowej,

- $\quad$ tory kolejowe z szyn bezstykowych na podkładach drewnianych lub zygzakowatych betonowych, na podsypce thuczniowej,

- szyny nie spawane na podsypce thuczniowej, szyny stykowe lub pojedyncze zwrotnice,

- $\quad$ tory kolejowe na betonowych podkładach bez podsypki,

- $\quad$ tory kolejowe na betonowych podkładach umieszczonych na podsypce tłuczniowej,

- $\quad$ tory kolejowe $\mathrm{z}$ nastawnym mocowaniem szyn, bez podsypki (głownie na wiaduktach)

- $\quad$ tory kolejowe $\mathrm{z}$ nastawnym mocowaniem szyn na podsypce thuczniowej,

- $\quad$ tory $\mathrm{z}$ wbudowanymi szynami

- $\quad$ tory kolejowe na przejeździe kołowym

Autorzy metody podkreślają, iż wyznaczenie współczynnika korekcji dla torów nie jest proste. Każdorazowo określa się wartości dla poszczególnych pasm oktawowych oraz osobno wartości dla każdej kategorii pojazdu szynowego.

Metoda RMR 1996 określa pięć możliwych wysokości pomiarowych (wysokości źródeł dźwięku):

- $\quad 0.0 \mathrm{~m}$ - na wysokości główki szyny,

- $\quad 0.5 \mathrm{~m}$ powyżej główki szyny,

- $\quad 2.0 \mathrm{~m}$ powyżej główki szyny,

- $\quad 4.0 \mathrm{~m}$ powyżej główki szyny,

- $\quad 5.0 \mathrm{~m}$ powyżej główki szyny,

Trzy ostanie wysokości pomiarowe dotyczą wyłącznie pociągów dużych prędkości.

\begin{tabular}{|c|c|c|c|c|c|c|c|c|c|c|}
\hline Kategoria & 1 & 2 & 3 & 4 & 5 & 6 & 7 & 8 & 9 & 10 \\
\hline Max. prędkość $[\mathrm{km} / \mathrm{h}]$ & 140 & 160 & 140 & 100 & 140 & 120 & 100 & 160 & 300 & 330 \\
\hline
\end{tabular}


Według metody SRM I równoważny poziom dźwięku powodowany ruchem kolejowym określa się w następujący sposób:

$$
L_{\text {Aeq }}=E_{s}+C_{\text {reflection }}-D_{\text {dis tance }}-D_{\text {air }}-D_{\text {soil }}-D_{\text {meteo }}
$$

gdzie:

$E_{s}$ - złożona wartość emisji obliczana wg równania:

$$
E_{s}=10 \lg \frac{1}{127} \sum_{i=1}^{n} \phi_{i} 10^{E_{i} / 10}
$$

gdzie:

$E_{i}$ - wartość emisji odcinka i (określona w $§ 2$ opracowania [6])

$\phi_{i}$ - kąt przy odcinku i, widziany z punktu odbioru

$n$ - numer odcinka w granicach rozpatrywanej powierzchni

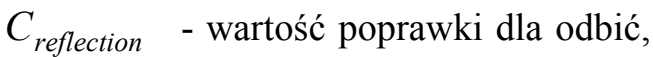
jeśli występują, pochodzących od budynków lub innych płaszczyzn odbijających

$$
C_{\text {reflection }}=f_{o b j}
$$

gdzie:

$f_{o b j}$ - całkowita długość odcinka (równoległy do toru i prostopadły do punktu odbioru) po drugiej stronie badanego toru przez który rozprzestrzenia się dźwięk od odbitej powierzchni w zakresie

$$
4\left(d_{r}+d_{w}\right)
$$

$d_{r}$ - odległość pomiędzy obiektem odbijającym a źródłem [m]

$d_{w}$ - odległość pomiędzy punktem odbioru a źródłem [m]

$D_{\text {distance }}$ - wartość obniżająca poziom dźwięku, zależna od odległości

$$
D_{\text {distance }}=10 \lg r
$$

gdzie:

$r$ - najkrótsza odległość pomiędzy punktem odbioru a źródłem liniowym $[\mathrm{m}]$

$D_{\text {air }}$ - wartość obniżająca poziom dźwięku, wynikająca z pochłaniania przez atmosfere

$$
D_{\text {air }}=0.016 r^{0.9}
$$

gdzie:

$r$ - najkrótsza odległość pomiędzy punktem odbioru a źródłem liniowym [m]

$D_{\text {soil }} \quad$ - wartość obniżająca poziom dźwięku, wynikająca $\mathrm{z}$ pochłaniania przez grunt

$D_{\text {soil }}=3 B^{0.5}\left(1-e^{-0.03 r}\right)\left(1.25 e^{-0.75\left(0.6 h_{b s}+0.5\right)}+e^{-0.9 h_{w}}\right)+$

$+1.6 B-1.8-3(1-B)\left(1-e^{\frac{-0.01 r}{h_{w}+h_{b s}+0.4}}\right)$

gdzie:

$B$ - współczynnik pochłaniania przez grunt, odcinek gruntu pomiędzy punktem odbioru a źródłem - niewybrukowany np. tłuczeń, trawa, grunty rolne uprawne lub nie, piaski, grunty na których nie uprawia się warzyw

$r \quad$ - najkrótsza odległość pomiędzy punktem odbioru a źródłem liniowym [m]

$h_{b s}$ - wysokość źródła powyżej średniego poziomu terenu wewnątrz obszaru źródła $[\mathrm{m}]$

$h_{w}$ - wysokość punktu odbioru powyżej średniego poziomu terenu wewnątrz ocenianego obszaru $[\mathrm{m}]$

$D_{\text {meteo }}$-wartość poprawki dla warunków meteorologicznych

$$
D_{\text {meteo }}=3.5\left(1-e^{-0.04 \frac{r}{h_{w}+0.6 h_{b s}+0.5}-5}\right)
$$

Jeśli wynik jest wartością ujemną, współczynnik $D_{\text {meteo }}$ przyjmuje wartość zero.

Według metody SRM II równoważny poziom dźwięku w odległości $\mathrm{r}$ od źródła określa się $\mathrm{W}$ następujący sposób:

$$
L_{\text {Aeq }}=10 \lg \sum_{i=1}^{8} \sum_{j=1}^{J} \sum_{n=1}^{N} 10^{\Delta L_{e q, i, j, n} / 10}
$$

gdzie:

$\Delta L_{e q, i, j, n^{-}}$określony udział w paśmie oktawowym $i$ sektora $j$ i źródła punktowego $n$

$$
\Delta L_{e q, i, j, n}=L_{E}+\Delta L_{G U}-\Delta L_{O D}-\Delta L_{S W}-\Delta L_{R}-58.6
$$

gdzie:

$L_{E}$ - wartość emisji dla danej wysokości źródła w paśmie oktawowym

$\Delta L_{G U}$ - rozbieżność geometryczna i kierunkowość

$$
\Delta L_{G U}=10 \lg \frac{\phi \sin v}{r}
$$


gdzie:

$r$ - odległość pomiędzy źródłem i punktem pomiarowym, mierzona wzdłuż najkrótszej linii łączącej te punkty [m],

$v$ - kąt pomiędzy sektorem powierzchni i odcinkiem źródła liniowego [w stopniach],

$\phi$ - kąt otwarty sektora [w stopniach].

$\Delta L_{O D}$ - thumienie z powodu propagacji

$$
\Delta L_{O D}=D_{L}+D_{B}+C_{M}
$$

gdzie:

$D_{L}$ - wpływ powietrza,

$D_{B}$ - wpływ gruntu,

$C_{M}$ - współczynnik korekcji meteorologicznej.

$\Delta L_{S W}$ - efekt ekranowania, jeśli występuje

$$
\Delta L_{S W}=H F\left(N_{f}\right)-C_{p}
$$

gdzie:

$H$ - skuteczność ekranowania,

$F\left(N_{f}\right)$ - funkcja z argumentem $N_{f}$ (= liczbie

Fresnela),

$C_{p}$ - współczynnik korekcji zależny od profilu.

$\Delta L_{R}$ - thumienie z powodu odbić, jeśli występują

$$
\Delta L_{R}=N_{r e f} \boldsymbol{\delta}_{r e f}
$$

gdzie:

$N_{\text {ref }}$ - liczba odbić pomiędzy źródłem a punktem pomiarowym

$\delta_{\text {ref }}$ - obniżenie poziomu wskutek odbicia

$\delta_{\text {ref }}=-10 \log _{10}(0.8)$ dla budynków, w całym zakresie pasma oktawowego

$\delta_{r e f, i}=-10 \log _{10}\left(1-\alpha_{i}\right)$ dla powierzchni pochłaniających, w paśmie oktawowym $i$

$\delta_{\text {ref }}=1$ dla każdej innej powierzchni, w całym zakresie pasma oktawowego

$\alpha_{i}$ - współczynnik pochłaniania dźwięku w paśmie oktawowym $i$

2.2. Metoda niemiecka Schall $03 \mathrm{z}$ 1990r. - (,Richtlinie zur Berechnung der Schallimmissionen von Schienenwegen") [7]

Schall 03 to jedna ze starszych metod wyznaczania poziomu hałasu generowanego przez pojazdy szynowe opracowana w 1990r. dla Kolei niemieckich (Deutsche Bundesbahn).
Metoda ta określa poziom mocy akustycznej źródła emisji $L_{m, E} \quad$ (dotyczy źródła) według następującej zależności:

$L_{m, E}=10 \cdot \log \left[\sum_{i} 10^{0,1 \cdot\left(51+D_{F z}+D_{D}+D_{l}+D_{v}\right)}\right]+D_{F b}+D_{B r}+D_{B u}+D_{R a}$

Zawiera liczne dodatkowe składniki - poprawki odnoszące się zarówno do pojazdu jak i torów.

\section{Poprawki odnoszące się do pojazdu:}

$D_{F z}$ - wpływ typu pojazdów szynowych (wartości zawarte w tabeli 2)

$D_{D} \quad$ - wpływ rodzaju hamulca

$$
D_{D}=10 \lg (5-0,04 \cdot p)
$$

gdzie:

$p$ - procentowy udział hamulców tarczowych w składzie pociągu (łącznie z lokomotywa)

$D_{l} \quad$ - wpływ długości pociągu

$$
D_{l}=10 \lg (0,01 \cdot l)
$$

gdzie: $l$ - suma długości pociągów w danej klasie na godzinę

przyjmuje się:

- długość lokomotywy 20 [m]

- długość wagonu pasażerskiego 26,4 [m]

$D_{v} \quad$ - wpływ prędkości pociagu

$$
D_{v}=20 \lg (0,01 \cdot v)
$$

gdzie: $v$ - dopuszczalna prędkość na danym odcinku

Poprawki odnoszące się do torów:

$D_{F b} \quad$ - wpływ torowiska (wartości zgodnie z tabelą 3),

$D_{B r} \quad$ - wpływ mostu $D_{B r}=3 d B$,

$D_{B u} \quad$-wpływ przejazdów kolejowych

$D_{B u}=5 d B$,

$D_{R a}$ - wpływ łuku torowego.

Wpływ rodzaju pojazdu $D_{F z}$ Tabela 2

\begin{tabular}{|c|l|c|}
\hline Lp. & \multicolumn{1}{|c|}{ Rodzaj pojazdu } & $D_{F z}{ }^{*}$ \\
\hline 1 & $\begin{array}{l}\text { Pojazdy poruszające się z dopuszczalną } \\
\text { prędkością } V>100 \mathrm{~km} / \mathrm{h}, \\
\text { wyposażone w koła absorbujące hałas } \\
\text { (np. Typ 401) }\end{array}$ & -4 \\
\hline 2 & $\begin{array}{l}\text { Pojazdy wyposażone w koła z hamul- } \\
\text { cami tarczowymi (Typ 403, 420, 472) }\end{array}$ & -2 \\
\hline 3 & $\begin{array}{l}\text { Pojazdy wyposażone w koła z hamul- } \\
\text { cami tarczowymi (wagony typu } B x, \\
\text { lącznie z lokomotywa) }\end{array}$ & -1 \\
\hline 4 & Metro & 2 \\
\hline 5 & Tramwaje & 3 \\
\hline 6 & Pozostałe rodzaje pojazdów & 0 \\
\hline
\end{tabular}


Wpływ rodzaju toru $D_{F b}$ Tabela 3

\begin{tabular}{|c|l|c|}
\hline Lp. & \multicolumn{1}{|c|}{ Rodzaj torowiska } & $D_{F b}{ }^{*}$ \\
\hline 1 & $\begin{array}{l}\text { Torowiska pokryte trawa } \\
\text { - trawmwaje }\end{array}$ & -2 \\
\hline 2 & $\begin{array}{l}\text { Torowiska na podsypce thuczniowej } \\
\text { - podkłady drewnianie }\end{array}$ & 0 \\
\hline 3 & $\begin{array}{l}\text { Torowiska na podsypce tłuczniowej } \\
\text { - podkłady betonowe }\end{array}$ & 2 \\
\hline 4 & Płyty betonowe - nie absorbujące & 5 \\
\hline
\end{tabular}

Do obliczeń wykorzystywane są również następujące dane:

- rodzaj pojazdu - wyróżnia się 14 kategorii pojazdów (tabela 4),

Prędkości oraz dlugości różnych kategorii pojazdów

Tabela 4

\begin{tabular}{|c|l|c|c|}
\hline Lp. & \multicolumn{1}{|c|}{ Kategoria pojazdu } & $\begin{array}{c}\text { Max. } \\
\text { prędkość } \\
{[\mathrm{km} / \mathrm{h}]}\end{array}$ & $\begin{array}{c}\text { Średnia } \\
\text { dlugość } \\
{[\mathrm{m}]}\end{array}$ \\
\hline 1 & ICE & 250 & 420 \\
\hline 2 & EC/IC & 200 & 340 \\
\hline 3 & Pociągi regionalne & 200 & 205 \\
\hline 4 & $\begin{array}{l}\text { D - pociagi pospieszne } \\
\text { FD - pociagi dalekobieżne }\end{array}$ & 160 & 340 \\
\hline 5 & Pociagi przyspieszone & 140 & 205 \\
\hline 6 & Pociagi podmiejskie & 120 & 150 \\
\hline 7 & $\begin{array}{l}\text { Pociagi kolei dojazdowych } \\
\text { (Zespoły trakcyjne) }\end{array}$ & 120 & 130 \\
\hline 8 & $\begin{array}{l}\text { Pociagi kolei dojazdowych } \\
\text { (Berlin) }\end{array}$ & 100 & 70 \\
\hline 9 & $\begin{array}{l}\text { Pociagi kolei dojazdowych } \\
\text { (Hamburg) }\end{array}$ & 100 & 130 \\
\hline 10 & $\begin{array}{l}\text { Pociagi kolei dojazdowych } \\
\text { (Nadrenia-Zagłębie Rury) }\end{array}$ & 120 & 120 \\
\hline 11 & $\begin{array}{l}\text { Pociagi towarowe } \\
\text { (dalekobieżne) }\end{array}$ & 100 & 500 \\
\hline 12 & $\begin{array}{l}\text { Pociagi towarowe } \\
\text { (regionalne) }\end{array}$ & 90 & 200 \\
\hline 13 & Metro & 80 & 80 \\
\hline 14 & Tramwaje & 25 \\
\hline
\end{tabular}

- rodzaj hamulca (tabela 5),

Procentowy udział hamulców tarczowych w skladzie pociągu

Tabela 5

\begin{tabular}{|c|l|c|c|}
\hline \multirow{2}{*}{ Lp. } & \multirow{2}{*}{ Kategoria pojazdu } & \multicolumn{2}{|c|}{$\begin{array}{c}\text { Procentowy udział ha- } \\
\text { mulców tarczowych } \\
\text { na pojeździe }\end{array}$} \\
\cline { 3 - 4 } & & do $1988 \mathrm{r}$. & do $2000 \mathrm{r}$. \\
\hline 1 & $\begin{array}{l}\text { D - pociagi pospieszne } \\
\text { FD - pociagi daleko- } \\
\text { bieżne }\end{array}$ & $30 \%$ & $100 \%$ \\
\hline 2 & $\begin{array}{l}\text { Pociagi przyspieszone } \\
\text { Pociagi podmiejskie }\end{array}$ & $20 \%$ & $30 \%$ \\
\hline 3 & Pociagi towarowe & $0 \%$ & $0 \%$ \\
\hline 4 & $\begin{array}{l}\text { wszystkie inne katego- } \\
\text { rie pojazdów }\end{array}$ & $100 \%$ & $100 \%$ \\
\hline
\end{tabular}

- długość i skład pociagu (tabela 4),

- prędkość (tabela 4),

- mosty,

- przejazdy kolejowe,

- łuki toru.

\section{3.,Schall 03 2006“ - Nowa metoda niemiecka [8]}

Nowa, niemiecka metoda służąca do wyznaczania poziomu hałasu generowanego przez pojazdy szynowe, opracowana została wg zharmonizowanej metody obliczeniowej zawartej w Dyrektywie 2002/49/UE i opublikowana na międzynarodowej konferencji EURONOISE, która odbyła się w 2006r. w Tampere (Finlandia).

Obecnie stosowana metoda zawiera także liczne, parametry odnoszące się zarówno do pojazdu jak i torów. Metoda bazuje na poziomach dźwięku wyznaczanych w pasmach oktawowych, opisuje emisję hałasu na rożnych wysokościach dla różnych kategorii pojazdów (np.: lokomotywy elektryczne, spalinowe, wagony pasażerskie towarowe, itp.), źródeł hałasu (hałas toczenia, hałas aerodynamiczny, hałas zespołu maszyn, hałas od silnika) oraz elementów źródeł hałasu (np.: chropowatość kół i szyn, hałas od pantografu oraz hałas od wentylatorów, wózków itp.).

Poziom mocy akustycznej emisji na jednostkę długości dla źródła zastępczego $L_{W^{\prime} A, f, h, m, F z}$ opisany jest następującym równaniem:

\section{3.,Schall 03 2006“ - Nowa metoda niemiecka [8]}

Nowa, niemiecka metoda służąca do wyznaczania poziomu hałasu generowanego przez pojazdy szynowe, opracowana została wg zharmonizowanej metody obliczeniowej zawartej w Dyrektywie 2002/49/ UE i opublikowana na międzynarodowej konferencji EURONOISE, która odbyła się w 2006r. w Tampere (Finlandia).

Obecnie stosowana metoda zawiera także liczne, parametry odnoszące się zarówno do pojazdu jak i torów. Metoda bazuje na poziomach dźwięku wyznaczanych w pasmach oktawowych, opisuje emisję hałasu na rożnych wysokościach dla różnych kategorii pojazdów (np.: lokomotywy elektryczne, spalinowe, wagony pasażerskie towarowe, itp.), źródeł hałasu (hałas toczenia, hałas aerodynamiczny, hałas zespołu maszyn, hałas od silnika) oraz elementów źródeł hałasu (np.: chropowatość kół i szyn, hałas od pantografu oraz hałas od wentylatorów, wózków itp.).

Poziom mocy akustycznej emisji na jednostkę długości dla źródła zastępczego $L_{W^{\prime} A, f, h, m, F z}$ opisany jest następującym równaniem:

$$
\begin{aligned}
& L_{W^{\prime} A, f, h, m, F z}=a_{A, h . m . F z}+\Delta a_{f, h, m, F z}+10 \lg \frac{n_{Q}}{n_{Q, 0}} d B+ \\
& +b_{f, h, m} \lg \left(\frac{v_{F z}}{v_{0}}\right) d B+\sum c_{f, h, m}+\sum K
\end{aligned}
$$


gdzie:

$a_{A, h, m, F z}$ - poziom A mocy akustycznej przypadającej na jednostkę długości dla prędkości odniesienia $V_{0}=100 \mathrm{~km} / \mathrm{h}$ na torze $o$ średniej jakości powierzchni szyn

$\Delta a_{f, h, m, F z}$ - różnica poziomu w pasmach oktawowych $\mathrm{f} w \mathrm{~dB}$,

$n_{Q} \quad$ - ilość źródeł dźwięku na jednostce pojaz$\mathrm{du}$,

$n_{Q, 0}$ - liczba odniesienia źródeł dźwięku na jednostce pojazdu,

$b_{f, h, m}$ - współczynnik prędkości,

$v_{F z} \quad$ - prędkość,

$v_{0} \quad$ - prędkość odniesienia, $v_{0}=100 \mathrm{~km} / \mathrm{h}$

$c_{f, h, m}$ - poprawki poziomu dla rodzaju toru i powierzchni szyny,

$K_{\text {_ }} \quad$ poprawki poziomu dla mostów i uciążliwości hałasu.

Dalszy sposób wyznaczania poziomu dźwięku jest zgodny z metodą zalecaną w normie ISO 9613-2.

\subsection{Metoda stosowana w Anglii ("Calculation of Rail Traffic Noise") [9] [21]}

Metoda wyznaczania poziomu hałasu generowanego przez pojazdy szynowe stosowana w Anglii, w skrócie nazywana (CRN), stosowana jest m.in. w oprogramowaniu do tworzenia map akustycznych SoundPLAN. Pojazd szynowy traktowany jest jako źródło liniowe.

Rodzaje pojazdów szynowych oraz poprawka $C_{1}$

Tabela 6

\begin{tabular}{|c|c|}
\hline Rodzaj pojazdu & $\begin{array}{c}\text { Poprawka } C_{1} \\
{\left[\mathrm{~dB}_{(\mathrm{A})}\right]}\end{array}$ \\
\hline \multicolumn{2}{|c|}{ Wagony pasażerskie - hamulce klockowe } \\
\hline - EMU klasa 421 lub 422 & 10.8 \\
\hline - Koleje Brytyjskie MK I lub II & 14.8 \\
\hline \multicolumn{2}{|c|}{ Wagony pasażerskie - hamulce tarczowe, 4 osiowe } \\
\hline - EMU klasa 319 & 11.3 \\
\hline - EMU klasa 465 i 466 & 8.4 \\
\hline - EMU klasa 165 i 166 & 7.0 \\
\hline - Koleje Brytyjskie MK III lub IV & 6.0 \\
\hline Wagony pasazerskie - hamulce tarczowe, 6 osiowe & 15.8 \\
\hline Wagony pasażerskie - hamulce tarczowe, 8 osiowe & 14.9 \\
\hline Wagony towarowe - hamulce klockowe, 2 osiowe & 12.0 \\
\hline Wagony towarowe - hamulce klockowe, 4 osiowe & 15.0 \\
\hline Wagony towarowe - hamulce tarczowe, 2 osiowe & 8.0 \\
\hline Wagony towarowe - hamulce klockowe, 2 osiowe & 7.5 \\
\hline \multicolumn{2}{|l|}{ Lokomotywy spalinowe (ustalona prędkość) } \\
\hline - Klasa 20 i 33 & 14.8 \\
\hline - Klasa $31,37,47,56,59,60$ & 16.6 \\
\hline - Klasa 43 & 18.0 \\
\hline \multicolumn{2}{|l|}{ Lokomotywy spalinowe pod petnym obciażeniem } \\
\hline - Klasa 20,31,33,37,43,47,56,59 & 0.0 \\
\hline - Klasa 60 & -5.0 \\
\hline Lokomotywy elektryczne & 14.8 \\
\hline $\begin{array}{l}\text { Eurostar - hałas toczenia } \\
\text { (2 napędne wagony rozdzielone } 14 \text { lub } 18 \text { wagonami) }\end{array}$ & 17.2 \\
\hline $\begin{array}{l}\text { Eurostar - hałas wentylatorów } \\
\text { ( } 2 \text { napędne wagony rozdzielone }\end{array}$ & $-7,4$ \\
\hline
\end{tabular}

Metoda określa rodzaje pojazdów (tabela 6) oraz torów (tabela 7) a także poprawki korygujące różnicę pomiędzy poszczególnymi kategoriami:

Rodzaje szyn/torów oraz poprawka Tabela 7

\begin{tabular}{|l|c|}
\hline \multicolumn{1}{|c|}{ Opis szyn } & $\begin{array}{c}\text { Poprawka } \\
{\left[\mathrm{dB}_{(\mathrm{A})}\right]}\end{array}$ \\
\hline Szyny stykowe & 2,5 \\
\hline Rozjazdy i skrzyżowania & 2,5 \\
\hline Tory na płytach betonowych & 2,0 \\
\hline $\begin{array}{l}\text { Betonowe mosty i wiadukty } \\
\text { (wykluczając ekranowanie przez bariery) }\end{array}$ & 1,0 \\
\hline $\begin{array}{l}\text { Stalowe mosty } \\
\text { (wykluczając ekranowanie przez bariery) }\end{array}$ & 4,0 \\
\hline $\begin{array}{l}\text { Szyny bezpośrednio połączone z dźwiga- } \\
\text { rem skrzynkowym }\end{array}$ & 9,0 \\
\hline
\end{tabular}

Obliczenia hałasu kolejowego wg. metody CRN przeprowadza się w następujący sposób:

1) Pojedyncze pojazdy $S E L_{v}$

- dla pojazdów nienapędnych:

$S E L_{v}=31.2+20 \log _{10} v+C_{1}$

- dla lokomotyw przy pełnej mocy:

$S E L_{v}=112.6-10 \log _{10} v+C_{1}$

$C_{1}$ - poprawka odnosząca się do pojazdu (tabela 7)

2) $S E L_{T}$ dla pociagów o identycznym składzie

3) $S E L_{v}$ przy każdej prędkości

$$
S E L_{v}=S E L_{T}-10 \log _{10} N
$$

4) Całkowita wartość $S E L$ dla każdego pociagu o identycznym składzie $S E L_{T i}$ :

$$
S E L_{T i}=S E L_{v}+10 \log _{10} N
$$

5) Obliczenia $S E L_{\operatorname{Re} f}$ dla każdego odcinka toru według udziału pociągów o identycznym składzie $S E L_{T i}$

$$
S E L_{\operatorname{Re} f}=10 \log _{10} \sum_{i=1}^{N_{T}} 10^{S E L_{T_{i}} / 10}+\text { po- }
$$

prawka od toru

6) Skorygowana wartość $S E L$ w punkcie odbioru

$$
\begin{aligned}
& S E L=S E L_{\text {ref }}+C_{\text {dist }}+C_{\text {abs }}+ \\
& +\max \left(C_{\text {ground }} C_{\text {barrier }}\right)+ \\
& +C_{\text {view }}+C_{\text {reflection }}
\end{aligned}
$$

7) Dla każdego rodzaju toru na każdym odcinku toru obliczamy $L_{A e q}$ :

$$
L_{A e q, 6 h}=S E L-43.3+10 \log _{10} Q_{N I G H T}
$$


$L_{A e q, 18 h}=S E L-48.1+10 \log _{10} Q_{D A Y}$

$Q_{N I G H T}$ - jest liczbą pociagów tego samego typu, przejeżdżających przez punkt odbioru w okresie czasu: 00.00 $-06.00$

$Q_{D A Y}$ - jest liczbą pociągów tego samego typu, przejeżdżających przez punkt odbioru w okresie czasu: 06.00 $-00.00$

8) Obliczamy całkowita wartość $L_{\text {tot }}$ poprzez połączenie składowych $L_{\text {Aeq }}$

$$
L_{\text {tot }}=10 \log _{10}\left(\sum_{i} 10^{L_{t} / 10}\right)
$$

CRN określa również współczynniki (poprawki) na tłumienie wynikające $\mathrm{z}$ propagacji hałasu kolejowego w atmosferze (rysunek 3 ):

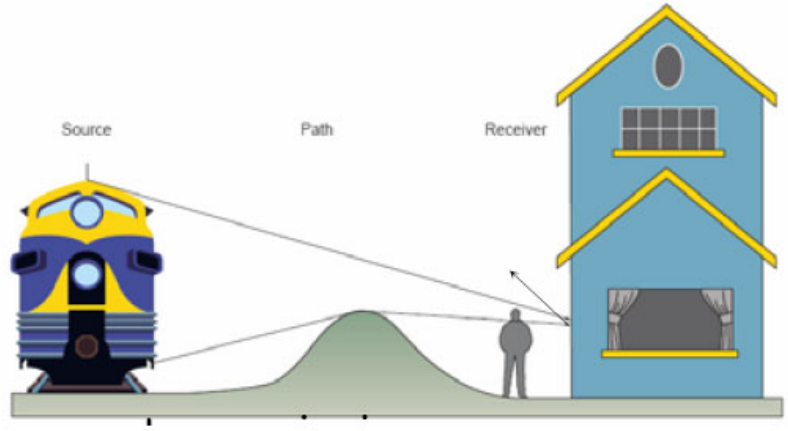

Rys.3. Propagacja hałasu w atmosferze

- thumienie związane z odległością:

$$
C_{\text {dist }}=-10 \log _{10}\left(d^{\prime} / 25\right), d^{\prime}>10 m
$$

gdzie: $d$ ' - jest odległością od odcinka toru do punktu odbioru

- thumienie przez atmosferę

$$
C_{a b s}=0,2-0,008 d \text {, }
$$

- tłumienie przez grunt

$$
C_{\text {ground }}=\left\{\begin{array}{l}
-3 P_{d} \log _{10}(d / 25) \\
-0,6 P_{d}(6-H) \log _{10}(d / 25) \\
0
\end{array}\right.
$$

$$
\left.\begin{array}{l}
H \leq 1 m \\
1<H<6 m \\
H>6 m \text { lub } 10<d<25 m
\end{array}\right\}+C_{\text {ballast }}
$$

gdzie: $d$ - jest składową poziomą odległości od odcinka toru do obserwatora,
$H$ - jest średnią wysokością propagacji (wysokość źródła + wysokość w punkcie odbioru)/2 - dla terenu płaskiego

$P_{d}$ - jest to stopień pochłaniania gruntu pomiędzy źródłem a punktem odbioru

$$
C_{\text {ballast }}=\left\{\begin{array}{l}
-1,5 d B^{* 1} \\
0 d B^{* 2}
\end{array}\right.
$$

*1 dla wszystkich odcinków toru, $\mathrm{z}$ wyjątkiem najbliższego obserwatorowi,

$$
\text { położonych na podsypce }
$$

*2 jeśli tory nie leżą na

podsypce

- poprawka na ekranowanie

Strefa cienia

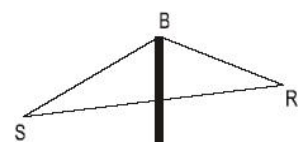

$$
\begin{aligned}
& C_{\text {barrier }}=\left\{\begin{array}{l}
-7.75 \log _{10}(5.2+203 \delta) d B A \\
-21 d B
\end{array}\right. \\
& \left.\begin{array}{l}
0<\delta<2.5 m \\
\delta>2.5 m
\end{array}\right\}
\end{aligned}
$$

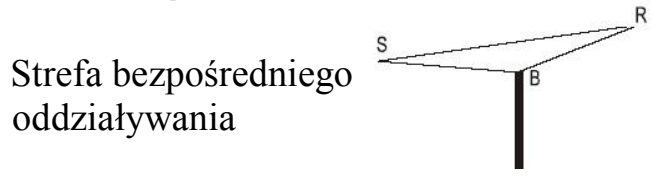

$C_{\text {barrier }}=\left\{\begin{array}{l}0.88+2.14 \log _{10}(\delta+0.001) d B A \\ 0 d B\end{array}\right.$

$\left.\begin{array}{l}0<\delta<0.4 m \\ \delta>0.4 m\end{array}\right\}$

gdzie: $\delta=S B+B R-S R$ - jest różnicą długości drogi od źródła do punktu odbioru

- poprawka na kat widzenia

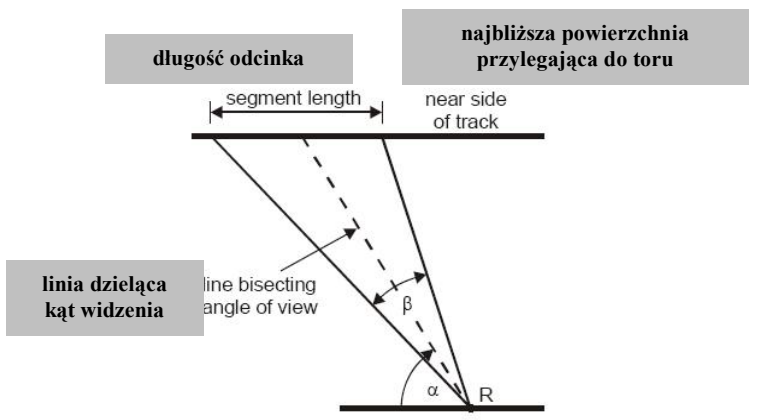




$$
\begin{aligned}
& C_{\text {view }}=\left\{\begin{array}{l}
0 \\
-10 \log _{10}(\sin \alpha \sin (\beta / 2)) \\
10 \log _{10}(\beta-\cos (2 \alpha) \sin (\beta))-5
\end{array}\right. \\
& \left.\begin{array}{l}
\alpha \leq \beta / 2 \\
\alpha>\beta / 2^{* 1)} \\
\alpha>\beta / 2^{* 2)}
\end{array}\right\}
\end{aligned}
$$

*1) \& lokomotywy spalinowe pod pełnym obciążeniem

${ }^{* 2)} \&$ inne (nie spalinowe) lokomotywy pod pełnym obciążeniem

- poprawka na odbicia

$$
C_{\text {reflection }}=\sum\left\{\begin{array}{l}
+2.5 d B A^{* 1)} \\
+2.5 d B A^{* 2)} \\
+1.5 d B A^{* 3)}
\end{array}\right.
$$

*1) jeśli punkt odbioru znajduje się $1 \mathrm{~m}$ od fasady budynku

${ }^{* 2)}$ jeśli punkt odbioru znajduje się po drugiej stronie ulicy (z budynkami), prostopadle do linii kolejowej

*3) jeśli punkt odbioru znajduje się

\subsection{Metoda stosowana w Austrii („ÖAL 30”) [10]}

Metoda, opisana i stosowana w oprogramowaniu do tworzenia map akustycznych SoundPLAN. Wykorzystywana jest na trzy sposoby, pierwszy, standardowy opisujący emisję i propagację hałasu w pasmach oktawowych. Drugi, pozwala na zastosowanie metody do kalibracji modelu dla różnych pojazdów szynowych. Trzeci, stosuje ustalone standardy do wyznaczenia propagacji dźwięku.

Poziom dźwięku w punkcie odbioru $L_{i}$ od elementu toru określany jest równaniem:

$L_{i}=L_{w}-11+10 * \log ($ dlugosc odcinka $)$ $+20 * \log (1 /$ odleglos $\phi+10 * \log (0.15+0.85 * \operatorname{sqr}(S) / \operatorname{sqr}(R))$

w którym do wartości poziomu mocy akustycznej odcinka toru odniesionego do $1 \mathrm{~m}$ dodaje się następujace wartości poprawek:

$+10 * \log$ (dlugosc odcinka) poprawka na dhugość odcinka dla źródła zastępczego,

$+20 * \log (1 /$ odleglosc $)$ spadek poziomu wraz z odległością,

$+10 * \log (0.15+0.85 * \operatorname{sqr}(S) / \operatorname{sqr}(R)) \quad$ kierunkowość pociągu,
+ pochłanianie przez powietrze,

+ pochłanianie przez grunt,

+ ekranowanie.

2.6. Metoda wykorzystywana w Szwajcarii (,Schweizerisches Emissions- und Immissionsmodell für die Berechnung von Eisenbahnlärm") [11]

Model akustyczny stosowany w Szwajcarii nazywany $\mathrm{w}$ skrócie SEMIBEL, opracowany został $\mathrm{w}$ 1990r. Określa równoważny poziom dźwieku wg następującego równania:

$$
\begin{gathered}
L_{e q, z}=\text { Summe }\left\{\begin{array}{l}
\left.A(w)+B(w) \cdot \log \mid v_{e f f}(z)\right]+ \\
+10 \cdot \log [\operatorname{Lange}(w)]+10 \cdot \log [M(z))
\end{array}\right\} \\
L r, e=L_{e q, e}+F+K 1
\end{gathered}
$$

gdzie:

$L_{e q, z} \quad$ - ocena emisji hałasu pociagów $z$, $\mathrm{dB}(\mathrm{A})$

$L_{e q, e} \quad$ - poziom emisji odcinka, $\mathrm{dB}(\mathrm{A})$

$L_{r, e} \quad$ - poziom emisji odcinka, $\mathrm{dB}(\mathrm{A})$

$w \quad$ - typ wagonu

$z \quad$ - typ pociagu

$v_{\text {eff }} \quad$ - prędkość średnia, $\mathrm{km} / \mathrm{h}$

$l(w) \quad-$ długość danego typu wagonu $w$, $\mathrm{m}$

$M(z) \quad$ - ilość pojazdów danej kategorii pociagów na godzinę, $\mathrm{Z} / \mathrm{h}$

$F \quad$ - poprawka dotycząca torów, dB(A)

K1 - poprawka poziomu dla hałasu jazdy, dB(A)

2.7. Slowacka metoda (,Metodické pokyny pre výpočet hladín hluku od dopravy”) [12]

Metoda wykorzystywana na Słowacji do wyznaczania równoważnego poziomu dźwięku pojazdów szynowych obliczana wg równania:

$$
Y=40+10 \cdot \log X
$$

gdzie:

parametr X obliczany jest wg następującej formuly :

$$
X=140 \cdot F_{4} \cdot F_{5} \cdot F_{6} \cdot m
$$

gdzie:

$F_{4}$ - współczynnik wpływu trakcji,

$F_{4}=1,0$ - dla trakcji spalinowej;

$F_{4}=0,65$ - dla trakcji elektrycznej

$F_{5}$ - współczynnik wpływu prędko-

ści jazdy na odcinku pomiarowym, 


$$
F_{5}=0,241 \cdot e^{(0,024 \mathrm{~V})}
$$

$F_{6}$ - współczynnik średniej ilości pojazdów (wagonów i lokomotyw) w składzie

$$
F_{6}=0,0375 z-0,5
$$

$m$ - średnia liczba pociągów pasażerskich podczas godziny

$V$ - prędkość pojazdu

\subsection{Metoda stosowana $w$ krajach skandynawskich (,nordtest method") [13]}

Metoda sporządzona w roku 1997, zawiera procedurę pomiaru równoważnego poziomu dźwięku od ruchu kolejowego zarówno na zewnątrz jak i wewnątrz budynków a także w otwartej przestrzeni. Metoda wykorzystuje do obliczeń następujące parametry:

- typ pociagu,

- prędkość i długość pojazdu,

- pora dnia w której wykonuje się pomiary,

- inne znaczące elementy.

Wyznaczenie wartości $L_{A e q}$ dla wybranego okresu dnia lub całego dnia dokonuje się wg zależności:

$$
\begin{aligned}
& L_{e q, T}=-10 \lg (3600 T)+ \\
& +10 \lg \left[10^{L_{A E, t y p e, 1 / 10}}+10^{L_{A E, t y p e, 2 / 10}}+\ldots\right] d B
\end{aligned}
$$

gdzie:

$L_{A E, 1}, \quad L_{A E, 2} \quad$ itd. - ekspozycyjne poziomy dźwięku poszczególnych typów pojazdów,

$T$ - czas pomiaru w godzinach, dla wybranego okresu dnia lub dla całego dnia

$L_{A E, t y p e}=10 \lg \left[\left(\frac{L_{t y p e}}{L_{t y p e_{1}}}\left(10^{L_{A E, 1 / 10}}+10^{L_{A E, 2 / 10}}+\ldots+10_{A E, n / 10}\right)\right)\right] d B$

gdzie:

$L_{\text {type }}$ - całkowita długość danego typu pojazdu w rozważanym okresie dnia

$L_{\text {type,1 }}$ - długość pociagów, danego typu pojazdu w serii pomiarowej

2.9. Metoda stosowana $w$ krajach skandynawskich (,Nord 2000. New Nordic Prediction Method for Rail Traffic Noise") [14]

Nowsza z metod opracowana dla Szwecji, Norwegi i Danii wykorzystywana do wyznaczania poziomu dźwięku od pojazdów szynowych. Metoda zawiera bardzo szczegółowy opis obliczeń, rodzaje parametrów wchodzących w skład modelu.
Model propagacji pozwala na określenie poziomu ciśnienia akustycznego w punkcie odbioru r, wyznaczany w pasmach tercjowych w zakresie $25 \mathrm{~Hz}-$ $10 \mathrm{kHz}$ wg zależnosci:

$$
L_{R}=L_{W}+\Delta L_{d}+\Delta L_{a}+\Delta L_{t}+\Delta L_{s}+\Delta L_{r}
$$
gdzie:

$L_{W} \quad$ - poziom mocy akustycznej w granicach rozpatrywanego pasma częstotliwości, $\Delta L_{d}$ - efekt thumienia rozbieżności sferycznej energii dźwięku

$$
\Delta L_{d}=-10 \lg \left(4 \pi R^{2}\right)
$$

gdzie:

$R \quad$ - jest odległością pomiędzy źródłem a punktem odbioru

$\Delta L_{a}$ - efekt thumienia wynikający z pochłaniania przez atmosferę, obliczany jest na podstawie ISO 9613-1,

$\Delta L_{t}$ - efekt thumienia terenu (grunt i bariery),

$\Delta L_{s}$ - efekt thumienia stref rozpraszajacych,

$\Delta L_{r}$ - efekt wpływu odbić.

2.9. Metoda stosowana $w$ Egipcie („Noise prediction model for Egyptian railway lines inside urban areas") [15]

Również takie kraje jak Egipt wprowadziły własny model wykorzystywany do oceny poziomu hałasu kolejowego. Dla każdej kategorii pojazdów (eksploatowanych przez koleje egipskie) można stosować trzy różniące się typy wzorów:

- logarytmiczny:

$$
S P L=A \log (S)+B \log (d)+C \log (N)+D
$$

- liniowy:

$$
S P L=A(S)+B(d)+C(N)+D
$$

- wykładniczy:

$$
S P L=\operatorname{Exp}[A(S)+B(d)+C(N)+D]
$$

gdzie:

$S P L$ - poziom ciśnienia akustycznego $(\mathrm{dB})$,

$S \quad-$ prędkość pociągu $\mathrm{w} \mathrm{km} / \mathrm{h}$,

$d \quad-$ odległość od toru $\mathrm{w} \mathrm{m}$,

$N \quad$ - liczba wagonów w składzie pocią-

gu,

$A, B, C, D$ - stałe współczynniki (różne dla każdego wzoru).

Przeprowadzone badania hałasu na kolejach egipskich dla różnych warunków posadowienia toru oraz pociagów wykazały że najmniejsze błędy uzyskano dla modelu liniowego. 


\subsection{Metoda stosowana na Węgrzech („Vasúti közlekedés zajkibocsátásának számítása") [16]}

Metoda węgierska opublikowana została w normie MZS 07-2904-1990. Równoważny poziom dźwięku obliczany jest na podstawie danych z ruchu dla referencyjnej odległości $25 \mathrm{~m}$ od najbliższej osi toru, na wysokości $0.5 \mathrm{~m}$ nad główką szyny, dla pory dziennej $(6: 00 \div 22: 00)$ i pory nocnej $(22: 00 \div 6: 00)$.

Równoważny poziom dźwięku obliczany jest wg. zależnosci:

$$
L_{\text {Aeq,i }}(25)=L_{0 i}+10 \cdot \lg Q_{i}+10 \cdot \lg \frac{l_{i}}{l_{0 i}}+20 \cdot \lg \frac{v_{i}}{v_{0 i}}
$$

gdzie:

$L_{0 i} \quad$ - poziom hałasu emitowany przez pojazd szynowy $(\mathrm{dB})$,

$Q_{i} \quad$ - średnia liczba przejeżdżających pociągów w ciagu godziny,

$l_{i} \quad$ - długość pociągu [m],

$l_{0 i} \quad$ - długość pociagu odniesienia [m],

$v_{i} \quad$ - prędkość pociagu $\mathrm{km} / \mathrm{h}$,

$v_{0 i} \quad$ - prędkość odniesienia $\mathrm{km} / \mathrm{h}$.

\subsection{Metoda przedstawiona $w$ normie PN-ISO 9613-2 [17]}

Przedstawiony w normie model obliczeniowy thumienia hałasu pochodzącego od zbioru źródeł punktowych zalecany jest głównie do obliczeń hałasu generowanego przez przemysł jednak pewne jego elementy mogą być wykorzystane do prognozowania hałasu w obrębie dróg kolejowych.

Równoważny poziom ciśnienia akustycznego w pasmach oktawowych w punkcie odbioru dla propagacji z wiatrem przedstawia się następująco:

$$
L_{f T}(D W)=L_{W}+D_{C}-A
$$

gdzie:

$L_{W}$ - poziom mocy akustycznej punktowego źródła dźwięku w paśmie oktawowym $[\mathrm{dB}]$

$D_{C}$ - współczynnik kierunkowości źródła $[\mathrm{dB}]$,

$A$ - współczynnik kierunkowości źródła $[\mathrm{dB}]$,

$$
A=A_{d i v}+A_{\text {atm }}+A_{g r}+A_{b a r}+A_{\text {misc }}
$$

gdzie:

\footnotetext{
$A_{d i v}$ - tłumienie wynikające $\mathrm{z}$ rozbieżności geometrycznej,
}

$A_{\text {atm }}$ - thumienie wynikające $\mathrm{z}$ pochłaniania przez atmosferę,

$A_{g r}$ - tłumienie wynikające z wpływu gruntu,

$A_{b a r}$ - thumienie wynikające $\mathrm{z}$ obecności ekranu,

$A_{\text {misc }}$ - tłumienie wynikające $\mathrm{z}$ różnych innych zjawisk,

\subsection{Model opracowany w Akademii Górniczo -} Hutniczej w Krakowie [18]

Przedstawiony poniżej model opublikowany został w materiałach konferencyjnych RAILWAY NOISE w 1999 r. Określa on sposób wyznaczenia równoważnego poziomu dźwięku A w punkcie obserwacji od i-tego źródła:

$$
\begin{aligned}
& L_{\text {Aeqi }}=L_{\text {Aeqi } / 1 m}+L_{\Theta}-L_{r}-L_{E}-L_{g r}-L_{z}-L_{\text {pow }} \\
& \text { gdzie: } \\
& L_{\text {Aeqi/1m }} \text { - równoważny obliczeniowy poziom } \\
& \text { dźwięku A w odległości 1m od i-tego } \\
& \text { źródła } \\
& \text { punktowego, } \\
& L_{\Theta} \quad \text { - poprawka określająca charaktery- } \\
& \text { stykę kierunkową promieniowania, } \\
& L_{r} \quad \text { - poprawka uwzględniająca wpływ } \\
& \text { odległości, } \\
& L_{E} \quad \text { - poprawka na ekranowanie, } \\
& L_{g r} \quad \text { - poprawka uwzględniająca oddzia- } \\
& \text { ływanie gruntu, } \\
& L_{z} \quad \text { - poprawka uwzględniająca wpływ } \\
& \text { zieleni, } \\
& L_{\text {pow }} \quad \text { - poprawka uwzględniająca chłonność } \\
& \text { akustyczną powietrza. }
\end{aligned}
$$

\subsection{Model opracowany w Politechnice Wrocław- skiej [19]}

Model zaproponowany przez zespół pracowników Instytutu Telekomunikacji i Akustyki PW powstał w 1994 r. W okresie, w którym opracowali model nie istniały jeszcze konkretne zalecenia międzynarodowe dotyczące metod obliczania hałasu kolejowego.

Przedstawiony schemat metody obliczeniowej pozwala na korzystanie $\mathrm{z}$ dwóch możliwych wariantów obliczeń

- wariant bazujący na modelu źródła liniowego i standaryzowanych poziomach odniesienia dla pociagu,

- wariant bazujący na modelu szeregu źródeł punktowych i poziomie mocy akustycznej poszczególnych wagonów. 
Poniżej przedstawiono pierwszy wariant określający poziom dźwięku $\mathrm{w}$ dowolnym punkcie otoczenia, związany z przejazdem pociagu:

$$
L=\underset{\text { gdzie: }}{L_{o}+\Delta L_{r}-A_{p}-A_{g}-A_{e}-A_{f}}
$$

$L_{o} \quad-\max L_{A \max }$ lub ekwiwalentny $L_{A e q}$ poziom dźwięku pociągu lub lokomotywy podawany dla różnych typów pociągów lub lokomotyw w punkcie odniesienia [dB],

$\Delta L_{r}$ - zmiany poziomu dźwięku ze wzrostem odległości od źródła $[\mathrm{dB}]$,

$A_{p}$ - tłumienie dźwięku wprowadzane przez powietrze,

$A_{g} \quad$ - tłumienie dźwięku związane z zejściem fali akustycznej nad powierzchnią gruntu [dB],

$A_{e} \quad$ - dodatkowe thumienie wynikające $\mathrm{z}$ warunków prowadzenia linii kolejowej [dB],

$A_{f}$ - korekcja uwzględniająca wpływ powierzchni odbijających.

\section{Projekty HARMONOISE, IMAGINE [20]}

Realizacja programów HARMONOISE (Harmonised Accurate and Reliable Methods for the EU Directive on the Assessment and Management Of Environmental Noise) oraz IMAGINE (Improved Metods for the Assessment of the Generic Impact of Noise in the Environment) jest kontynuacja procesu harmonizacji metod i budowy standardu wspólnotowego. Zadaniem projektu Harmonoise było stworzenie inżynierskiego modelu oddziaływania hałasu komunikacyjnego, uwzględniającego drogi i koleje. Model inżynierski obowiązuje w zakresie od $25 \mathrm{~Hz}$ do $10 \mathrm{kHz}$. Obliczenia są wykonywane w pasmach $1 / 3$ oktawowych. Osiagany jest różny stopień dokładności w zależności od klasy dokładności wprowadzonych danych. Dokładność modelu zmniejsza się z odległością od źródła i dla nierównomiernego terenu.

\section{Podsumowanie}

W artykule przedstawiono przegląd modeli obliczeniowych stosowanych $\mathrm{w}$ różnych krajach na świecie. Modeli tych jest bardzo dużo, uwzględniają one różne parametry charakteryzujące m.in:

- warunki środowiskowe danego kraju (np.: rodzaj i gęstość zieleni, warunki atmosferyczne, rodzaj gruntu);

- warunki techniczne pojazdów (np.: wpływ rodzaju klocków hamulcowych);

- $\quad$ stan torów, podtorza;
- kategorię pojazdów (elektryczne, spalinowe, pasażerskie, towarowe)

- położenie trasy kolejowej (nasyp, prosta, zagłębienie) itd.

Dokładność modeli obliczeniowych zależy m.in. od poprawnego doboru parametrów, ich ilości oraz dokładnej analizy ich wpływu na ostateczną wartość poziomu dźwięku (niektóre $\mathrm{z}$ tych parametrów mają nieznaczny wpływ, inne wręcz przeciwnie).

Poszczególne metody prognozowania hałasu są trudne do porównania również ze względu na odległość pomiarową, czas trwania pomiaru lub też porę dnia w której wykonuje się badania.

Ważnym zauważalnym wnioskiem jest to, iż istnieje niewątpliwa potrzeba stworzenia modelu (metody obliczeniowej) poziomu hałasu generowanego przez pojazdy szynowe dla polskich warunków zgodnie $\mathrm{z}$ obowiązującymi obecnie przepisami czy też adaptacja jednego z już istniejących.

Ze względu na ograniczoną objętość artykułu wszystkie przedstawione modele (metody) nie zostały opisane szczegółowo, przedstawiono jedynie ich istotę.

\section{Literatura}

[1] Dyrektywa 2001/16/WE Parlamentu Europejskiego oraz Rady Unii Europejskiej $z$ dnia 19 marca 2001 r. w sprawie interoperacyjności transeuropejskiego systemu kolei konwencjonalnych

[2] Dyrektywa 2002/49/WE Parlamentu Europejskiego oraz Rady Unii Europejskiej $z$ dnia 25 czerwca 2002 r. $w$ sprawie oceny $i$ kontroli poziomu hałasu w środowisku

[3] EN ISO 3095 ,Railway applications - Acoustics - Measurement of noise emitted by railbound vehicles"

[4] Prawo Ochrony Środowiska z dnia 27.04.2001r.

[5] Reken-en Meetvoorschrift Railverkeerslawaai 96? Ministerie Volkshuisvesting, Ruimtelijke Ordening en Milieubeheer, 20 November 1996"

[6] AR-INTERIM-CM (CONTRACT: B43040/2001/329750/MAR/C1), Adaptation and revision of the interim noise computation methods for the purpose of strategic noise mapping, WP 3.2.1: Railway Noise - Description of the calculation method,

[7] „Richtlinie zur Berechnung der Schallimmissionen von Schienenwegen - Schall 03 “, information-Deutsche Bundesbahn-Akustik 03, Ausgabe 1990

[8] U. Moehler, M. Liepert, U. Kurze, H. Onnich „The new German prediction model for railway noise ,Schall 032006 "-some proposals for the harmonised calculation method in the EU Directive on Environmental Noise", Euronoise 2006, 30.05-01.06, Tampere 
[9] SoundPLAN, „, Calculation of Rail Traffic Noise CoRTN" Chapter 6-6.3.2.4, str. 92-96

[10] SoundPLAN, "ÖAL 30" Chapter 6-6.3.2.3, str. 89-92

[11] SEMIBEL „Schweizerisches Emissions- und Immissionsmodell für die Berechnung von Eisenbahnlärm", Schriftenreihe Umweltschutz Nr. 116. Herausgegeben vom Bundesamt für Umwelt, Wald und landschaft Bern, März 1990

[12] M.Liberko „,,Metodické pokyny pre výpočet hladin hluku od dopravy", Brno 1991

[13] ,nordtest method" NT ACOU 098, project 115094, zatwierdzony w 05.1997

[14] „Nord2000. Comprehensive Outdoor Sound Propagation Model. Part 1 Propagation in an Atmosphere without Significant Refraction, DELTA 31.12.2000r., str. 11

[15] Akram S. M. Kotb „Noise prediction model for Egyptian railway lines inside urban areas"

[16] A. Pultznerova "Comparision of some calculation models for railway noise prediction" Zeszyty Naukowe Politechniki Ślaskiej 2005 na podstawie MZS 07-2904-1990,,Vasúti közlekedés zajkibocsátásának számitása”, 1990
[17] PN-ISO 9613-2 „Akustyka - Zmniejszanie się rozchodzenia dźwięku $w$ wolnym powietrzu, Część 2: Ogólne metody obliczania"

[18] Adamczyk J., Stryczniewicz L., „,Modelowanie akustyczne linii kolejowych" RAILWAY NOISE 99

[19] M.Rabiega, A.Jaroch „Halas ruchu kolejowego metody predykcji" Prace Naukowe Instytutu Telekomunikacji i Akustyki Politechniki Wrocławskiej Nr 78, 1994

[20] M. Rabiega, L. Jakielaszek, A.Jaroch „Harmonizacja europejskich metod obliczania hatasu kolejowego"

[21] P.A. Meehan ,Railway noise and control" Calculation of Railway Noise (CRN)

[22] 2006/66/WE Decyzja komisji z dnia 23.12.2005r. dotyczaca technicznej specyfikacji dla interoperacyjności odnoszacej się do podsystemu ,tabor kolejowy - hałas" transeuropejskiego systemu kolei konwencjonalnych. 